\title{
Kepemimpinan Guru Di Laboratorium Teknik Jaringan Komputer Dalam Mengembangkan Karakter Disiplin Dan Kreatif Siswa Smk
}

\author{
Imran \\ STMIK AKBA Makassar, Pendidikan Teknologi Informasi \\ Email : $\underline{\text { imran@akba.ac.id }}$
}

\begin{abstract}
$\underline{\text { Abstrak }}$
Tujuan penelitian ini untuk mengetahui (1) bagaimana kepemimpinan guru dalam mengembangkan karakter disiplin siswa melalui pembelajaran pada laboratorium Teknik Komputer dan Jaringan (TKJ), (2) bagaimana kepemimpinan guru dalam mengembangkan karakter kreatif siswa melalui pembelajaran pada laboratorium Teknik Komputer dan Jaringan (TKJ). Penelitian ini menggunakan pendekatan deskriptif kualitatif, yaitu untuk memahami makna dibalik kegiatan pembelajaran yang nampak, untuk memahami interaksi guru dan siswa, untuk memahami perasaan guru dan siswa, untuk mengembangkan teori, dan untuk memastikan kebenaran data, Data dikumpulkan dengan metode studi observasi, wawancara, dan dokumentasi selanjutnya data tersebut dianalisis dengan langkah yang terstruktur yaitu mereduksi data, paparan/penyajian data penarikan kesimpulan. Hasil penelitian ini adalah: (1) bentuk kepemimpinan guru dalam pembelajaran di laboratorium teknik jaringan komputer (TKJ) untuk mengembangkan karakter disiplin siswa dapat terlihat dari metode pembiasaan, keteladanan, telling story, dan diskusi yang digunakan oleh guru laboratorium; (2) bentuk kepemimpinan guru dalam pembelajaran di laboratorium teknik jaringan komputer (TKJ) untuk mengembangkan karakter kreatif siswa terlihat dari metode pembiasaan, keteladanan, telling story, diskusi, dan simulasi yang digunakan guru laboratorium.
\end{abstract}

Kata Kunci : karakter disiplin, kreatif, kepemimpinan, pembelajaran, laboratorium TKJ

\section{Teacher Leadership In Computer Network Engineering Laboratory In Developing Discipline And Creative Character Of Students In Vocational School}

\begin{abstract}
$\underline{\text { Abstract }}$
The purpose of this study was to find out (1) how teacher leadership in developing students' disciplined character through learning in the Computer and Network Engineering laboratory (TKJ), (2) how teacher leadership in developing students' creative character through learning in the Computer and Network Engineering laboratory (TKJ). . This study uses a qualitative descriptive approach, namely to understand the meaning behind visible learning activities, to understand teacher and student interactions, to understand the feelings of teachers and students, to develop theories, and to ensure the validity of the data. and further documentation, the data is analyzed by structured steps, namely data reduction, exposure/presentation of conclusion drawing data. The results of this study are: (1) the form of teacher leadership in learning in the computer network engineering laboratory (TKJ) to develop students' disciplined character can be seen from the methods of habituation, example, telling stories, and discussions used by laboratory teachers; (2) the form of teacher leadership in learning in the computer network engineering laboratory (TKJ) to develop students' creative characters can be seen from the methods of habituation, example, telling stories, discussions, and simulations used by laboratory teachers.
\end{abstract}

Keywords: Role of LKP, Training Model, Entrepreneurship 


\section{Journal of Millennial Community, 3 (2), September 2021}

Imran

\section{PENDAHULUAN}

Guru sebagai figur dan garda terdepan sebagai pencetak masyarakat teladan baik dalam kehidupan sehari hari, kehidupan dalam dunia kerja dan kehidupan dalam berbangsa dan bernegara Dunia pendidikan sangat dinamis yang selalu bergerak dan selalu terjadi perubahan dan pembaharuan. Sekolah seolah terus berpacu untuk memunculkan dan mengejar keunggulannya masing-masing. Pada saat ini, banyak sekali peristiwa-peristiwa menyimpang yang mewarnai dunia pendidikan, baik dari peserta didik maupun penyimpangan yang dilakukan oleh pendidik. Hal tersebut dapat menjadikan indikasi bahwa secara kolektif maupun individual bangsa ini mengalami pelemahan karakter sebagai bangsa yang bermartabat mulia.

Lembaga pendidikan yang memiliki kemampua untuk menanamkan nilai karakter dalam proses mendidik siswa akan membuat mereka semakin relevan dalam tatanan masyarakat. Lembaga pendidikan demikian ini akan membantu membangun sebuah masyarakat yang sehat daripada sekedar mencetak para pekerja sosial, sukarelawan, dan konselor yang membantu mengatasi kemunduran sosial dalam masyarakat mereka. Untuk itu, beberapa inovasi-inovasi pembelajaran yang sudah ditawarkan oleh dunia pendidikan nasional untuk meningkatkan mutu dan kualitas pendidikan saat ini mulai diterapkan oleh lembagalembaga pendidikan. Seperti halnya di beberapa Sekolah Menengah Kejuruan (SMK) di kota Malang dan Makassar, telah merencanakan inovasi-inovasi pembelajaran yang berorientasi pada pembelajaran berbasis karakter baik di dalam kelas, di laboratorium maupun didalam pergaulan sehari-hari di lingkungan sekolah.

Menurut Khan (2010), Selain keluarga, lingkungan dan juga lembaga pendidikan mempunyai peran yang tidak kalah penting dalam proses pembentukan krakter bangsa, hal ini karena lembaga pendidikan adalah ujung tombak pembangunan bangsa dalam ranah edukasi formal. Pendidikan sebagai proses yang membantu mendewasakan, mengarahkan dan mengembangkan potensi dalam diri manusia dianggap sebagai sarana yang tepat dalam pembentukan karakter seseorang.

Menurut Thomas Lickona, karakter adalah Page|76 "A reliable disposition to respond to situations in a morally good way." Selanjutnya Thomas Lickona menambahkan bahwa "character so conceived has three interrelated parts: moral knowing, moral feeling, and moral behavior". Disini, Lickona menyatakan bahwa karakter itu terbentuk melalui tiga pilar utama, yaitu pengetahuan atau motivasi, perasaan dan perilaku. Dalam konteks pembangunan bangsa, pendidikan karakter merupakan usaha sadar dan terencana untuk mewujudkan suasana serta proses pemberdayaan potensi dan pembudayaan peserta didik guna membangun karakter pribadi atau kelompok yang diharapkan mampu memberikan kontribusi optimal dalam rangka mewujudkan masyarakat sebagaimana dimanatkan oleh Pancasila.

Sedangkan komponen utama dalam pendidikan karakter adalah guru, dan siswa. Guru merupakan komponen yang sangat menentukan keberhasilan pendidikan karakter di sekolah karena guru mempunyai hubungan yang sangat dekat dengan siswa dalam upaya pendidikan sehari-hari di sekolah. Dimana guru sebagai penanggung jawab keterlaksanaan proses pembelajaran di kelas maupun di laboratorium. Oleh sebab itulah guru berperan penting dalam keberhasilan pembelajaran karakter. Guru harus merancang pembelajaran secara baik, dalam arti mempertimbangkan tujuan pembelajaran yang akan dicapai, karakteristik siswa, merumuskan tujuan, menetapkan materi, memilih metode dan media, dan evaluasi pembelajaan yang tepat dalam rancangan pembelajarannya, hal tersebut dilakukan agar kegiatan pembelajaran berlangsung dan berhasil dengan sukses.

Dalam pembelajaran guru harus mampu berperan ganda, dimana guru tidak hanya mengajar saja, melainkan harus mampu 


\section{Journal of Millennial Community, 3 (2), September 2021}

Imran

menjadi programmer dalam pembelajaran, motivator belajar, fasilitator pembelajaran, organisator, aktor, dan peran-peran lain yang dibutuhkan oleh siswa dalam pembelajaran. Menurut Dwi (2012) meskipun guru bukan satu-satunya sumber belajar, tetapi tugas peranan dan fungsi guru dalam pembelajaran sangatlah penting dan berperan sentral. Pembelajaran itu sendiri adalah proses interaksi antara guru dengan siswa dan sumber belajar pada suatu lingkungan belajar (Ahmadi 2010). Pembelajaran merupakan bantuan dari guru kepada siswa dalam kondisi belajar agar siswa memperoleh pengetahuan, keterampilan, dan pembentukan sikap dan karakter.

Pendidikan karakter bagi siswa SMK merupakan hal yang mutlak sebab pendidikan karakter adalah modal dalam pengembangan kepribadian demi memenuhi tuntutan tenaga kerja kerja terampil, profesional dan memiliki moral yang baik untuk siap pakai oleh DUDI. Menurut Edy Sutrisno (2009), bahwa alasan perusahaan menerima karyawan salah satunya adalah mengecek tentang karakter calon yang berkaitan dengan moralitas dalam hal ini karakter disiplin dan karakter kreatif, dua karakter ini menurut Edy merupakan karakter yang mendasar yang harus dimiliki calon karyawan, karena jika seorang karyawan memiliki karakter disiplin yang baik maka karakter jujur, mandiri, tanggung jawab dan memiliki etos kerja yang tinggi cenderung dimilikinya. Sementara itu Ali \& Ashrori (2009), mengatakan seseorang yang memiliki karakter kreatif akan membuat seseorang peduli terhadap sesuatu yang berada di sekelilingnya dan seorang kreatif membuat hidup seseorang menjadi menyenangkan, karyawan yang mempunyai kreativitas dalam bekerja senang mencari pengalaman baru, memiliki ketekunan yang tinggi, cenderung kritis terhadap sesuatu yang menurutnya salah, Selalu ingin tahu, Berani mengemukakan pendapat dan keyakinannya, dan percaya diri sendiri yang kuat.

Mengingat begitu pentingnya dua karakter ini, yaitu karakter disiplin dan karakter kreatif maka SMK seharusnya terus melakukan pengembangan dan modifikasi dalam pembelajaran berbasis karakter. Untuk mengembangkan karakter disiplin dan kreatif pada siswa, guru selaku pimpinan pembelajaran di laboratorium memiliki peranan yang sangat penting sesuai dengan hasil penelitian yang dilakukan oleh Idochi \& M. Anwar (2010) yaitu, guru mempunya peran kepemimpinan dimana kepemimpinan adalah suatu kegiatan untuk mempengaruhi, mengarahkan, dan menggerakkan orang lain baik individu maupun kelompok untuk mencapai tujuan pembelajaran.

Pembelajaran yang sukses tergantung pada kemampuan guru dalam memimpin dan mengelola pembelajaran di laboratorium yang sesuai dengan tujuan yang telah ditentukan. Menurut Wahjosumidjo (1987), pada dasarnya tidak ada pemimpin yang baik, yang ada adalah pemimpin yang efektif, yaitu pemimpin yang selalu menyesuaikan perilakunya dengan tingkat perkembangan kedewasaan siswanya. Oleh karena itu, seorang pemimpin dapat berperilaku efektif, akan lebih cocok apabila pemimpin itu dapat menerapkan ajaran teori kepemimpinan situasi.

Lebih lanjut Idochi (2010) mengatakan, kepemimpinan guru adalah kemampuan seorang guru dalam mempengaruhi siswanya, sehingga siswa tersebut bertingkah-laku sebagaimana dikehendaki oleh guru tersebut. Menurut Purbakawaca (2009), kepemimpinan guru adalah suatu kesiapan, kemampuan yang dimiliki oleh seorang guru dalam proses mempengaruhi, mendorong, membimbing, mengarahkan dan menggerakkan siswanya yang ada hubungannya dengan pelaksanaan dan pengembangan proses pembelajaran, agar segenap kegiatan dapat berjalan secara efektif dan efisien dalam mencapai tujuan pembelajaran.

Berdasarkan uraian diatas maka penulis menganggap penting melakukan penelitian dan kajian untuk mengetahui bagaimana peran dan upaya kepemimpinan guru di laboratorium dapat mengembangkan karakter disiplin dan kreatif siswa di SMK, maka dengan 


\section{Journal of Millennial Community, 3 (2), September 2021}

Imran

alasan tersebut dirumuskanlah tujuan penelitian ini yaitu, untuk mengetahui bagaimana peran dan upaya kepemimpinan guru dalam mengembangkan karakter disiplin dan kreatif siswa melalui pembelajaran pada laboratorium Teknik Komputer dan Jaringan TKJ di SMK Telkom Sandy Putra yang ada di kota Malang dan SMK Negeri 5 yang terdapat di kota Makassar, dua SMK ini digunakan sebagai tempat pengambilan data mengingat kedua SMK merupakan SMK unggulan di kota masing-masing.

\section{METODE}

Penelitian ini menggunakan pendekatan deskriptif kualitatif, metode kualitatif digunakan karena beberapa pertimbangan, yaitu untuk memahami makna dibalik kegiatan pembelajaran yang nampak, untuk memahami interaksi guru dan siswa, untuk memahami perasaan guru dan siswa, untuk mengembangkan teori, untuk memastikan kebenaran data. Deskriptif artinya data yang diperoleh akan diuraiakan dalam bentuk uraian kata-kata dari apa yang dilihat, didengar, dirasakan dan ditanyakan selama penelitian berlangsung.

Jenis penelitian yang digunakan dalam penelitian ini adalah studi kasus dengan multi situs. Studi kasus/situs adalah penelitian yang bertujuan untuk mempelajari secara intensif mengenai unit sosial tertentu, yang meliputi individu, kelompok, lembaga dan masyarakat (Yatim 2011). Jenis penelitian ini dipilih karena peneliti ingin mengembangkan wawancara mendalam, observasi, dokumentasi serta triangulasi untuk menggambarkan kasus yang terjadi di SMK Sandi Putra Malang dan SMK Negeri 5 Makassar, yakni sejauh mana implementasi pendidikan karakter dalam kepemimpinan guru di laboratorium teknik jaringan komputer mengembangkan karakter disiplin dan kreatif siswa.

Penelitian ini dilaksanakan di SMK Sandi Putra Malang dimana SMK ini merupakan salah satu sekolah yang memiliki program studi teknik komputer dan jaringan yang terbaik di kota Malang dan SMKN 5 Makassar juga merupakan SMK unggulan di kota tersebut. Kedua SMK ini memiliki prestasi yang cukup banyak dan menurut peneliti cukup kompeten untuk dijadikan sebagai rujukan dalam pelaksanaan pendidikan karakter mengingat sekolah tersebut tingkat kekerasan dan tawuran antara siswa sangat kecil bahkan hampir tidak pernah terdengar. Sedangkan waktu penelitian dilaksanakan bulan Maret April 2017 tahun pelajaran 2017/2018.

Teknik pengumpulan data yang dipergunakan dalam penelitian ini adalah studi dokumentasi, wawancara, dan observasi. Menurut Arikunto (2002:135) metode dokumentasi menyelidiki benda-benda tertulis seperti buku-buku, majalah, dokumen, peraturan-peraturan, notulen rapat, catatan harian dan sebagainya. Studi dokumentasi ini, peneliti gunakan untuk mengumpulkan data tentang bagaimana pola mengajar guru didalam laboratorium sehingga dapat mengembangkan karakter disiplin dan kreatif siswa. Diantaranya RPP, Modul praktikum, SK guru laboratorium, buku pedoman laboratorium, tatertip penggunaan laboratorium, SOP laboratorium dan sebagainya yang dianggap dapat mendukung penelitian.

Wawancara merupakan percakapan verbal yang terarah pada kajian penelitian antara peneliti dengan subjek penelitian yang dipilih secara purposif. Wawancara ditujukan untuk memperoleh data (Arikunto 2002:132), bahwa wawancara digunakan oleh peneliti untuk mengetahui dan menilai keadaan seseorang misalnya bagaimana guru melakukan pembelajaran karakter, bagaimana dukungan kepala sekolah terhadap kepemimpinan guru di laboratorium, kebijakan apa saja yang diberikan kepala sekolah terhadap guru dalam mengembangkan karakter siswa, bagaimana prilaku guru, kepala sekolah dan murid ketika di laboratorium maupun di lingkungan sekolah dan seterusnya yang dapat mendukung data penelitian. 


\section{Journal of Millennial Community, 3 (2), September 2021}

Imran

Observasi merupakan metode pengumpulan data yang digunakan pada penelitian yang berkenaan dengan perilaku manusia, proses kerja, gejala-gejala alam dan untuk jumlah responden yang tidak terlalu besar (Sugiyono, 2009:2003). Dalam penelitian ini metode observasi digunakan karena penelitian ini ingin melihat perilaku guru dan proses belajar mengajar di dalam laboratorium yang ada di SMK Telkom Sandi Putra Malang dan SMKN 5 Kota Makassar. Pengamatan dilakukan terhadap prilaku guru dalam kepemimpinan di laboratotium dan prilaku guru terhadap pembentukan karakter disiplin dan kreatif siswa.

Subjek penelitian adalah benda, hal atau tempat data untuk variabel peneliti melekat dan yang dipermasalahkan. Subjek penelitian tidak selalu berupa orang, tetapi dapat berupa benda, kegiatan, tempat (Arikunto, 2002:11). Penelitian ini ingin megetahui bagaimana kepemimpinan guru di laboratorium SMK Sandi Putra Telkom Malang dan SMKN 5 Makassar, maka subjek dalam penelitian ini dapat dilihat pada table berikut ini:

Tabel 1. Subjek Pendukung Penelitian

\begin{tabular}{clc}
\hline No & Jabatan & Jumlah \\
\hline 1. & Kepala Sekolah & 2 \\
2. & Wakasek Kurikulum & 2 \\
3. & Guru Laboratorium TKJ & 6 \\
4. & Siswa & 30
\end{tabular}

Dalam menentukan subjek pendukung didasarkan atas pertimbangan bahwa subjek pendukung terlibat langsung dalam perencanaan penerimaan siswa baru, pelaksanaan siswa baru, sesuai dengan peranan dan wewenangnya masing-masing. Instrumen penelitian atau instrument pengumpulan data adalah alat bantu yang dipilih dan digunakan oleh peneliti dalam kegiatannya mengumpulkan data agar kegiatan tersebut menjadi sistematis dan dipermudah olehnya (Arikunto, 2006: 106). Dari pernyataan ini jelas bahwa pengembangan instrument penelitian bertujuan untuk alat mengumpulkan data yang digunakan peneliti dalam kegiatan mengumpulkan data agar kegiatan tersebut menjadi sistematis dan dipermudah.

Berdasarkan teknik pengupulan data yang digunakan, kisi-kisi instrument yang peneliti gunakan untuk memperoleh data penelitian terdiri dari pertanyaan yang mengambarkan variabel penelitian yang terdiri dari beberapa variabel yaitu: 1) bagaimana kepemimpinan guru di laboratorium, 2) bagaimana guru dalam mengembangkan karakter disiplin siswa; 3) bagaimana guru dalam mengembangkan karakter kreatif siswa. Data yang berhasil dikumpulkan dari lokasi penelitian, selanjutnya dianalisa dan kemudian disajikan secara tertulis dalam laporan, yaitu berupa data yang ditemukan dari observasi partisipan, wawancara mendalam, dan studi dokumentasi yang diperoleh dari SMK Telkom Sandi Putra Malang dan SMKN 5 Makassar. Adapun langkah-langkah yang diterapkan peneliti dalam menganalisa data yaitu mengikuti alur yang dinyatakan oleh Miles dan Huberman dalam Sugiyono (2009:246-53) bahwa analisis data terdiri dari tiga alur kegiatan yang terjadi secara bersamaan yaitu reduksi data, paparan/penyajian data dan penarikan kesimpulan yang dilakukan selama dan sesudah penelitian.

Pada saat kegiatan analisis data yang berlangsung secara terus menerus selesai dikerjakan, maka langkah selanjutnya adalah melakukan penarikan kesimpulan. Untuk mengarah pada hasil kesimpulan ini didasarkan pada hasil analisis data baik yang berasal dari catatan lapangan, obervasi partisipan, wawancara mendalam, dokumentasi yang didapat saat melakukan kegiatan di lapangan. Beberapa penilaian yang berhubungan dengan tujuan penelitian agar hasil penelitian yang didapat lebih akurat yaitu dilakukan dengan menetapkan bagaimana kepemimpinan guru di laboratorium dapat mengembangkan karakter disiplin dan kreatif siswa di SMK Sandi Putra Telkom Malang dan SMKN 5 Makassar. 


\section{Journal of Millennial Community, 3 (2), September 2021}

Imran

\section{HASIL DAN PEMBAHASAN}

\section{A. Kepemimpinan Guru Dalam Mengembangkan Karakter Siswa di Laboratorium}

Dalam pembentukan karakter siswa di SMK Sandi Putra Malang dang SMKN 5 Makassar melalui pembelajaran yang berlangsung di laboratorium tidak memiliki perbedaan yang signifikan. Metode-metode yang digunakan di dua SMK ini, adalah metode yang dirasa tepat atau sesuai dengan pembentukan karakter bagi calon tenaga kerja DUDI diantaranya adalah:

1. Metode Pembiasaan

Metode pembiasaan dilaksanakan sebagai cerminan dari budaya baik yang dibagun oleh sekolah dalam membina dan mendidik karakter siswa, sehingga pembiasaan yang dilaksanakan di laboratorium bisa tercapai pada kegiatan sehari-hari. Metode pembiasaan ini meliputi kegiatan-kegiatan atau program yang telah disusun sekolah dalam membina karakter disiplin peserta didik, seperti pembiasaan ${ }_{5} \mathrm{~S}$ (senyum, salam, sapa, sopan, dan santun), pembiasaan sholat dhuhur berjama'ah, membaca doa sebelum dan setelah praktikum, pembiasaan lingkungan bersih dan sehat. Dengan pembiasaan ini maka diharapkan pendidikan karakter akan tertanam didalam pribadi siswa sehingga saat mereka terlibat dalam DUDI karakter disiplin, religius, toleran, peduli lingkungan dan karakter lainnya mudah mereka lakukan karena sudah menjadi kebiasaan di laboratorium.

2. Metode Keteladanan

Metode keteladanan merupakan metode yang harus dilakukan, karena setiap hal yang dilakukan pendidik dalam pembelajaran atau ketika kegiatan di laboratorium merupakan hal yang nampak dan terlihat oleh siswa, sehingga siswa mudah meniru apa yang dilihatnya.

Dalam pelaksanaannya di SMKN 5 Makassar, keteladanan dilaksanakan dalam proses kegiatan itu sendiri, misalnya dalam kegiatan sholat berjama'ah, guru atau pendidik tidak hanya menyuruh peserta didik melaksanakan sholat tetapi juga mengajak dan ikut serta melaksanakan sholat (Faisal). Sehingga perbuatan yang dilakukan oleh guru akan mudah diikuti oleh siswa. Contoh lain keteladanan yang dilakukan di SMK Sandi Putra Malang, bahwa ada aturan yang melarang merokok dilingkungan sekolah dan itu lebih dahulu dilaksanakan oleh guru, dari pengamatan peneliti selama observasi berlangsung tidak sekali pun peneliti menemukan ada guru yang merokok dalam lingkungan sekolah apalagi merokok di dalam laboratorium sehingga larangan itu sangat terkesan terhadap siswa karena meraka dapat contoh langsung dari guru, begitupun larangan di dalam laboratorium misalnya larangan membawa makanan dan minuman yang lebih dulu di praktekkan oleh guru yang pengajar di laboratorium.

Metode keteladanan dilaksanakan sebagai wujud pemberian contoh baik yang dilakukan guru terhadap siswa. Metode ini berkaitan dengan kegiatan sehari-hari di laboratorium, seperti halnya keteladanan diatas dan beberapa keteralanan lainnya seperti dalam berperilaku sopan santun, bertutur kata yang baik, berpakaian rapi dan bersih, kedisiplinan, dan kegiatan pembiasaan lainnya yang dapat mengantarkan siswa ke pendidikan karakter.

Metode Bercerita, Mendongeng (Telling Story)

Metode ini sama dengan metode ceramah, tetapi guru lebih leluasa berimprovisasi. Hal yang penting guru harus membuat simpulan bersama peserta didik (tidak dalam kondisi terlalu formal) karakter apa saja yang diperankan para tokoh protagonis yang dapat ditiru oleh peserta didik, dan karakter para tokoh antagonis yang harus dihindari dan tidak ditiru para peserta didik.

Di SMK Sandi Putra Malang dan SMKN 5 Makassar dari hasil wawancara dengan beberapa siswa mengatakan bahwa: "metode yang digunakan yaitu ceramah" (Fitri), "metode yang digunakan yaitu metode ceramah" (Vita), "upayanya yaitu dengan menggunakan metodemetode seperti ceramah" (dyah), Dan "metode yang digunakan yaitu metode ceramah" (Agus). 


\section{Journal of Millennial Community, 3 (2), September 2021}

Imran

Dari hasil wawancara ini diindikasikan kuat bahwa selain metode praktek yang digunakan dilaboratorium guru juga menggunakan metode bercerita dan mendongeng (Telling Story).

4. Metode Diskusi

Diskusi merupakan sebagai proses bertukar pikiran antara dua orang atau lebih tentang sesuatu masalah untuk mencapai tujuan tertentu. Atau dapat juga didefinisikan diskusi adalah pertukaran pikiran (sharing of opinion) antara dua orang atau lebih yang bertujuan memperoleh kesamaan pandangan tentang sesuatu masalah yang dirasakan bersama.

Pada SMK Sandi Putra Malang dan SMKN 5 Makassar masing-masing menerapkan metode diskusi sebagaimana hasil wawancara dengan siswa dan guru di dua SMK tersebut yaitu menurut siswa "metode yang digunakan yaitu diskusi” (Firah), "upayanya yaitu dengan menggunakan metode diskusi" (Faisal), Dan oleh guru mengatakan "terkadang guru menggunakan metode diskusi ketika ada praktikum di laboratorium" (Anton Duty). Dari metode ini diharapkan ketajaman pendidikan karakter bagi siswa terus dikembangkan terutama karakter yang ditonjolkan dalam metode ini adalah karakter demokratis, toleransi, kreatif.

5. Metode Simulasi (Bermain Peranan/Role Playing)

Simulasi artinya peniruan terhadap sesuatu, jadi bukan sesuatu yang terjadi sesungguhnya. Dalam pembelajaran suatu simulasi dilakukan dengan tujuan agar peserta didik memperoleh keterampilan tertentu. Dapat pula simulasi ditujukan untuk memperoleh pemahaman tentang suatu konsep atau prinsip, serta bertujuan untuk memecahkan suatu masalah yang relevan dengan pendidikan karakter disiplin.

Materi-materi pembelajaran di program studi teknik komputer dan jaringan TKJ merupakan materi yang sangat tergantung pada perkembangan teknologi maka tidak bisa dipungkuri alat dan bahan peraktek itu harus juga selalu terbaru padahal sekolah sangat terbatas dalam biaya pendidikan maka pihak sekolah SMK itu tidak sedikit materi dilakukan dalam metode semulasi, tak ayal itu pula yang terjadi di laboratorium dua SMK yang menjadi tempat penelitian penulis. Hasil wawancara dengan guru dan siswa di SMK Sandi Putra Malang dan SMKN 5 Makassar, yaitu "metode yang digunakan yaitu metode simulasi" (Aras Wahyudi), "metode yang digunakan yaitu metode tanya simulasi" (M. Tahir), Dan wawancara dengan siswa mengatakan "metode yang digunakan yaitu metode simulasi” (dyah). Dari metode ini diharapkan siswa dapat mengembangkan karakter kreatif sebagaimana yang mereka pelajari dari materi yang terdapat pada simulasi penggunakan perangkat jaringan, siswa dapat membentuk sebuah jaringan local dengan kreativitas mereka sendiri sehingga dari kreativitas itu akan melahirkan sebuah pembelaran katakter.

Dari upaya pembelajran dengan empat metode diatas tersebut terdapat beberapa faktor yang mempengaruhi keberhasilan pendidikan karakter disiplin seperti penjelasan dari masing-masing guru mapel praktikum di laboratorim baik dari SMK Sandi Putra Malang maupun SMKN 5 Makasar mengatakan yaitu: "faktor eksternal dan faktor internal" (Anton Duty). "Kegiatan Belajar Mengajar (KBM), karena adanya KBM tersebut siswa menjadi berhasil" (Aras Wahyudi). "metode, kerja sama antara guru dengan siswa, sarana dan prasarana, dan siswa itu sendiri" (Drs. Nompo) "faktor internal, faktor eksternal, dan secara umum dari metode yang digunakan setiap mapel praktikum di laboratorium" (M. Tahir). "faktor lingkungan, faktor keluarga, faktor kebiasaan, dan faktor keturunan" (Ahmad Irfan) Dan "tergantung dari program sekolah tersebut” (Agus Setiawan).

\section{B. Hasil Kepemimpinan Guru Dalam Pengembangan Karakter Disiplin Siswa di Laboratorium}

Hasil dari pelaksanaan pembelajran pengembangan karakter disiplin bagi siswa di laboratorium, bisa dilihat dari perubahan sikap dan perilaku yang dialami siswa selama proses 


\section{Journal of Millennial Community, 3 (2), September 2021}

\section{Imran}

pembelajran di laboratorium maupun dilingkungan sekolah. Memang susah untuk mengidentifikasi perubahan sikap dan perilaku tersebut sehingga dapat dikatakan sebagai karakter disiplin mulia bagi siswa.

Disiplin terhadap peraturan di laboratorium dan di lingkungan sekolah, hasil dari nilai karakter disiplin juga terlihat dari program harian yang dilaksanakan, sehingga peserta didik terlatih untuk bertindak disiplin. Hal tersebut dibuktikan dengan disiplin ketika datang ke sekolah dan masuk di laboratorium, disiplin dalam mengerjakan tugas-tugas praktikum, dan terlihat dari antusias siswa terhadap program-program sekolah seperti menjaga kebersihan, doa sebelum praktikum dan sholat berjama'ah.

Tabel 2. Hasil yang menunjukkan cerminan dari nilai karakter disiplin

\begin{tabular}{|c|c|c|c|}
\hline $\begin{array}{l}\quad \text { Nilai } \\
\text { Pendidikan } \\
\text { Karakter }\end{array}$ & $\begin{array}{l}\quad \text { Metode } \\
\text { Yang } \\
\text { Digunakan }\end{array}$ & Indikator & Kegiatan Yang Mencerminkan \\
\hline \multirow[t]{4}{*}{ Disiplin } & Pembiasaan & \multirow{4}{*}{$\begin{array}{l}\quad \text { Menaati } \\
\text { peraturan } \\
\text { yang ada di } \\
\text { laboratorium } \\
\text { dan norma- } \\
\text { norma di } \\
\text { sekolah }\end{array}$} & $\begin{array}{l}\text { Siswa mencerminkan sikap dan perilaku } \\
\text { taat pada peraturan di laboratorium, dengan: }\end{array}$ \\
\hline & Telling Storv & & Masuk laboratorium tepat waktu, berpakaian \\
\hline & Diskusi & & $\begin{array}{l}\text { rapi dan sopan, melepas sepatu atau sandal, } \\
\text { menjaga kebersihan laboratorium, menjaga } \\
\text { peralatan laboratorium, menggunakan alat } \\
\text { dan bahan sesuai dengan kebutuhan dan } \\
\text { fungsinya, membawa modul praktikum, } \\
\text { masuk laboratorium setelah mendapatkan izin } \\
\text { dan dilarang membawa makanan dan } \\
\text { minuman,. }\end{array}$ \\
\hline & & & $\begin{array}{l}\text { Melakukan program pembiasaan seperti }{ }_{5} \mathrm{~S} \\
\text { (senyum, salam, sapa, sopan, dan santun), dan } \\
\text { berdoa sebelum memulai pembelajaran di } \\
\text { laboratorium }\end{array}$ \\
\hline
\end{tabular}

B. Hasil Kepemimpinan Guru Dalam Pengembangan Karakter Kreatif Siswa di Laboratorium

Hasil dari pembelajaran pengembangan karakter kreatif bagi siswa. Memang susah untuk mengidentifikasi perubahan sikap dan perilaku tersebut hingga dapat dikatakan sebagai karakter kreatif siswa. Namun kreativitas yang dihasilkan dari produk dalam bentuk tugas individu maupun tugas kelompok setidaknya dapat disimpulkan bawa siswa telah memiliki karakter kreatif yang mereka peroleh dari pembelajaran di laboratorium. Hasil yang menunjukkan cerminan dari nilai karakter kreatif tersebut yaitu: 
Journal of Millennial Community, 3 (2), September 2021

Imran

Tabel 3. Hasil Kepemimpinan guru dalam pengembangan karakter kreatif siswa

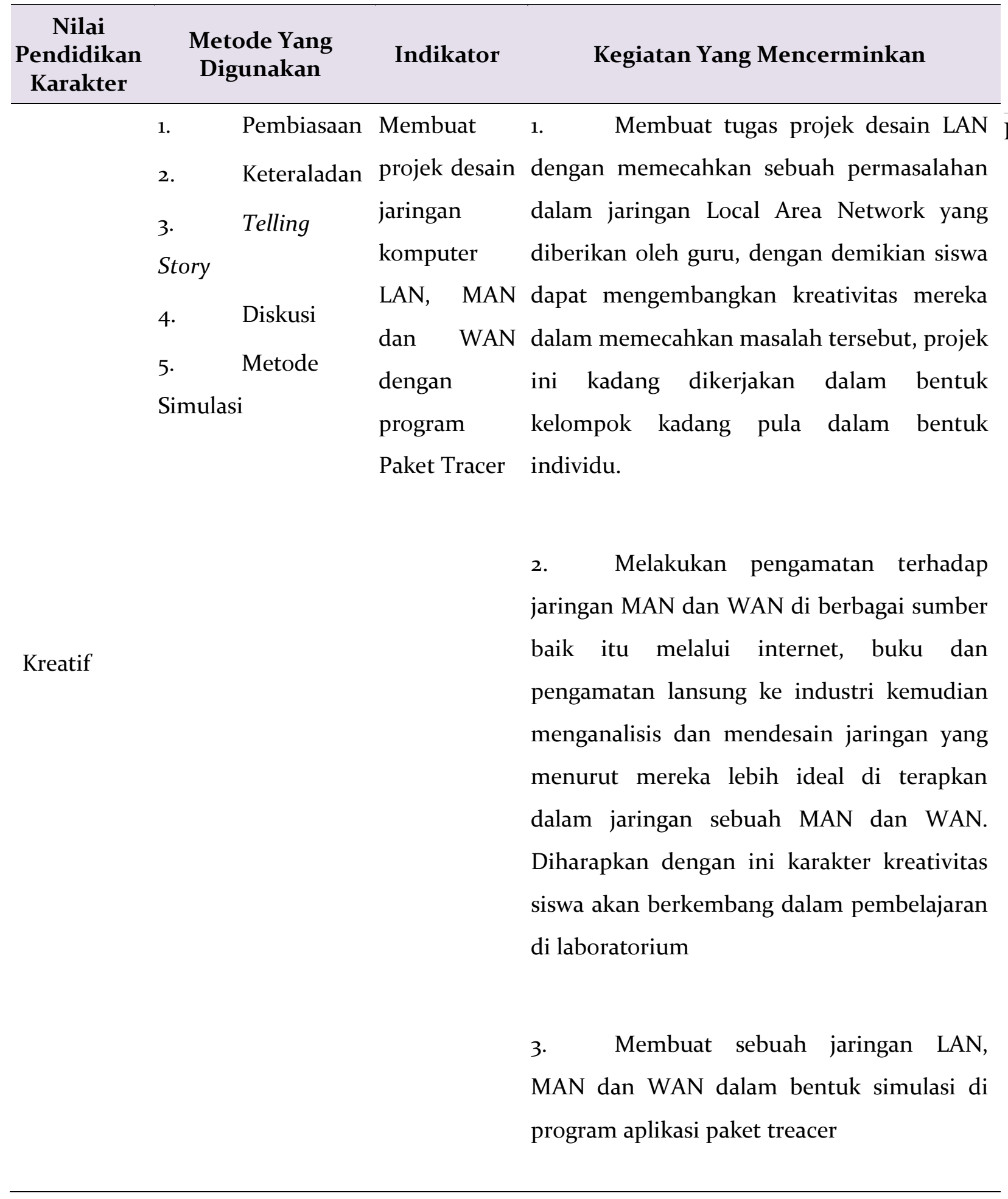




\section{Analisis Data Kepemimpinan Guru Dalam Pengembangan Karakter Siswa di Laboratorium}

Dari beberapa narasumber yang peneliti wawancarai dan dari observasi yang telah dilakukan serta dokumentasi yang diperoleh, peneliti memperoleh data tentang upaya guru laboratorium dalam pengembangan karakter disiplin siswa di SMK Sandi Putra Malang dan SMKN 5 Makassar. Menurut Kepala SMK Sandi Putra Malang, pelaksanaan pendidikan karakter disiplin di SMK Sandi Putra Malang telah dilaksanakan sejak awal SMK ini berdiri, hanya saja aplikasi pendidikan karakter disiplin terlihat jelas ketika kurikulum 2013 diadakan. Karena Peranan guru laboratorium dalam pelaksanaan pembentukan karakter disiplin siswa di SMK adalah seperangkat sikap yang dimiliki oleh guru yang meliputi mendidik, mengajar, membimbing, melatih, dan mengevaluasi.

\section{SIMPULAN}

Tidak semua program yang telah dijalankan pada SMK dalam penelitian ini berjalan sesuai yang diharapkan. Tetapi paling tidak, ada karakter minimal yang telah siswa tunjukkan dalam sikap dan perilaku sehari-hari sebagai wujud dari terinternalisasinya nilai-nilai karakter pada diri siswa dilihat dari hasil kepemimpinan pembelajaran di laboratorium, dengan dibuktikan berdasarkan observasi dan wawancara yang didapatkan peneliti sudah tampak serta mencerminkan kegiatan yang berkarakter.

Meskipun SMK yang diteliti ini dapat memperbaiki tingkah laku siswa ketika mereka berada di sekolah dan bukti menunjukkan bahwa sekolah memang bisa, namun sangat mungkin dampak yang mampu bertahan lama pada karakter disiplin anak hilang apabila nilai-nilai yang diajarkan sekolah tidak didukung dari rumah. Karena suatu usaha untuk pengembangan karakter disiplin dan kreatif siswa semua itu tidak luput dari faktor-faktor yang mempengaruhi keberhasilan pendidikan karakter tersebut.
Nilai karakter disiplin dan kreatif yang tercermin pada peserta didik, seperti datang ke sekolah atau laboratorium tepat waktu, kemudian sebelum masuk peserta didik melaksanakan kegiatan sesuai panduan dan aturan praktikum, dapat menyelesaikap projek yang diberikan guru dengan cara mereka sendiri, pembentukan kelompok yang aktif, hasil karya dari simulasi pelajaran yang mempu bersaing dalam lomba, desain jaringan dan maintenancenya yang baik, melakukan program pembiasaan seperti ${ }_{5} \mathrm{~S}$ (senyum, salam, sapa, sopan, dan santun), dan sholat berjama'ah. Hal ini perlu untuk diperhatikan dan dipahami jangan sampai nilai karakter disiplin dan kreatif minimal yang menjadi fokus pendidik kepada siswa di dua SMK ini lalu mengabaikan nilai-nilai karakter yang lain. Seyogyanya kesemua nilai karakter bangsa diintegrasikan ke seluruh aspek pembelajaran serta administrasinya.

\section{DAFTAR PUSTAKA}

Agnes, 2013. Multicultural Character Building as an Alternative Assessment in Elt. ELTLT Conference Proceedings.

Ahmad Fatoni. 2017. The Strategy of Character Education in Globalization Era. International Journal Of Scientific \& Technology Research Volume 6, Issue o4, April 2017.

Ahmadi, Abu. 2010. Strategi Pembelajaran.Penerbit Pustaka Setia.Bandung.

Amat Jaedun, Eka Purwaningsih, Fistian Novita, M. Alwan Wiranata. (2012). Implementasi Pendidikan Karakter Terintegrasi Dalam Kegiatan Pembelajaran Pada SMK Jurusan Bangunan Di Daerah Istimewa Yogyakarta. Jurnal Pendidikan Teknologi dan Kejuruan, Volume 21, Nomor 1, Mei 2012.

Arikunto, Suharsimi. 2002. Prosedur Penelitian Suatu Pendekatan Praktek: PT. Rineka Cipta. Jakarta.

Atieka 2014. Character Building of Students With 
Counseling Services Approach. Journal of Guidance and Counseling.

Ayi Suherman, 2018. The Implementation of Character Education Values In Integrated Physical Education Subject In Elementary School. SHS Web of Conferences 42.

Ayi Suherman. 2018. The Implementation of Character Education Values in Integrated Physical Education Subject in elementary School. SHS Web of Conferences 42, 00045.

Byars, L.I and Leslie W., Rue, 2006. Human Resource Management: A Practical Approach, Harcourt Brace, New York.

Cassrud, A., \& Branbarck, M. 2011. Entrepreneurial Motivations: What Do We Still Need to Know? Journal of Small Business Management, 49(1), 9-26.

D. Yahya, Khan, 2010. Pendidikan Karakter Berbasis Potensi Diri Dalam Lingkungan pendidikan Baik di Dalam Kelas Maupun di Lingkungan Sekolah. Yogyakarta: Jurnal Internasional Publishing.

David E Murray Tanya J. McGill Danny Toohey Nik Thompson. 2017. Can Learners Become Teachers? Evaluating the Merits of Student Generated Content and Peer Assessment. Journal Title: Issues in Informing Science and Information Technology. United States.

Dwi Fatmawati. 2012. Pengaruh Kreatifitas Guru dan Kelengkapan Fasilitas terhadap Prestasi Belajar Ekonomi siswa Kelas XI IPS SMA DU I Jombang. Disertasi. Dipublikasikan. Universitas Islam Negeri Maulana Malik Ibahim, http://lib.uinmalang.ac.id/

Eka, 2017. Revisiting Character Education from Islamic Perspective. Journal of Islamic Studies Published by Kulliyyah of Education, International Islamic University Malaysia.

Ella Masita. 2013. Curriculum in Education and Character Building Program in New Zealand Primary Schools. $2^{\text {nd }}$ ELTLT Conference Proceedings, December 2013.

F.E. Freeks E G.A. Lotter, 2017. Waardes En Die Noodsaak Van 'N Karakter opvoedings program Binne Kollegeverband in Die Noord wesprovinsie: Verkenning En Voorlopige Voorstelle.

F.E. Freeks \& G.A. Lotter. 2011. Values and the need for a character education programme within the college context in the North-WePtage $\mid 85$ Province: exploration and preliminary proposals. Koers 76(3) 2011:577-598.

Fazel Ebrihiam Freeks. 2015. The influence of role-players on the character-development and character-building of South African college students. South African Journal of Education, Volume 35, Number 3, August 2015.

Frimadhona Syafri, Rini Susanti Wulandari. 2012. Storyline Approach as Enhancement Of Learning Foreign Language And Character Building At Elementary School. ELTL Conference Proceedings.

Ian B Puddey Email author, Annette Mercer, Sandra E Carr and William Louden, 2011 Potential influence of selection criteria on the demographic composition of students in an Australian medical school, Journal Title: BMC Medical Education, United Kingdom.

Idochi, Moch.Anwar.2010.Kepemimpinan Dalam Proses Pembelajaran. Penerbit Angkasa. Bandung

Iis Nurasiah, Din Azwar Uswatun, Arsyi Rizqia Amalia. 2017. Building Character and Literacy Skills of Primary School Students Through Puppet Contemplative Sukuraga. Vidyottama Sanatama, International Journal of Hindu Science and Religious Studies, Vol 1 No. 12017.

Iwan Irawan. 2013. Pengaruh Pendidikan Karakter Mahasiswa Terhadap Ketaatan Hukum (Studi Kasus di Kampus Universitas Bina Nusantara). HUMANIORA Vol.4 No.2 Oktober 2013: 1105-1115.

Kharisma Ilyyana, Emi Pujiastuti, Wuryanto. 2013. Keefektifan Model Pembelajaran Investigasi Kelompok Berbasis Pendidikan Karakter Terhadap Hasil Belajar. Journal of Mathematics Education 2 (1).

Kim Kim Min. 2017. The Value of Saemaul Undong: South Korea Community Character 
Booste. Vidyottama Sanatama, International Journal of Hindu Science and Religious Studies, Vol 1 No. 12017.

Marco Antonio Manota Sánchez, 2015. Classroom's climate and good teaching methods with vulnerable teenagers: further from academic contents, Journal Title: Contextos Educativos: Revista de Educación, Universidad de La Rioja, Spain.

Moleong, Lexy. J. 2004. Metode Penelitian Kualitatif. Remaja Rosdakarya. Bandung. Indonesia.

Muhadjir, Noeng, 1987. Ilmu Pendidikan dan Perubahan Sosial: Suatu Teori Pendidikan. Reka Sarasih. Yogyakarta. Indonesia.

Muhammad Iplih. 2017. The strategy of internalizing the values of the characters in alMumtaz Islamic Boarding School. Attarbiyah: Journal of Islamic Culture and Education, Vol. 2 No. 1, 2017, pp.79-103.

Nanik Suryani, Hengky Pramushinto. 2012. Pengembangan Pendidikan Karakter Dalam Mata Kuliah Evaluasi Pembelajaran Melalui Pendekatan Deep Approach to Learning. Jurnal Pendidikan Ekonomi Dinamika Pendidikan, Vol. VII, No. 2, Desember 2012, Hal. 120-129.

Nasution, S. 2002. Metode Researh. PT Bumi Aksara. Jakarta.

Novrian Satria Perdana, M.E. 2015. Character Education Model Based On Education in Islamic Boarding School. Edutech, Tahun 14, Vol.1, No.3, Oktober 2015.

Patton, M. 1990. Qualitative Evaluation and Research Method. California: Sage Publication.

Peraturan Pemerintah Republik Indonesia Nomor 19 Tahun 2005. Tentang Sistem Pendidikan Nasional. Jakarta.

Rivanda Putra, Indah Werdiningsih, E Ira Puspitasari. 2017. Decision Support System for Selection of High Achievers in Junior High School with VIKOR and TOPSIS Methods. Journal of Information Systems Engineering and Business Intelligence. Indonesia
Rue dan Byars. 2006:6. Managemant Development: SMES in Indonesia. Journal of Developmental Entrepreneurship, 12(1), 95-118.

Septi Widiyantari. 2011. Pengaruh Kreativitas Mengajar Guru Dan Disiplin Belajar Siswa Terhadap Prestasi Belajar Akuntansi. KajiaPlage | 86 Pendidikan Akuntansi Indonesia (ejournal). Vol 1 No 2. Universitas Negeri Malang.

Soekartini.2009. Meningkatkan Efektivitas Mengajar. Penerbit Pustaka Jaya. Jakarta.

Sugioyono. 2009. Metode Penelitian Pendidikan; Pendekatan Kuantitatif, Kualitatif dan $R$ \& D. Penerbit Alfabeta. Bandung.

Tri Marhaeni Puji Astuti, Elly Kismini, Kuncoro Bayu Prasetyo. 2014. The Socialization Model of National Character Education for Students in Elementary School through Comic. Jurnal Komunitas 6 (2) (2014): 260-270.

Utami Munandar. 2012. Kreatifitas dan Keberbakatan Strategi Mewujudkan Potensi Kreatif dan Bakat. Penerbit PT. Gramedia Pustaka Indonesia. Jakarta 